\title{
NOTES ON BIO-HISTORY: MICHEL FOUCAULT AND THE POLITICAL ECONOMY OF HEALTH
}

\begin{abstract}
In October 1974, Foucault gave three lectures in Rio de Janeiro on the archeology of the cure. This piece will comment on the first two, published a few years later in France with the original titles: Crise de la médicine ou crise de l'antimédicine? and La naissance de la médicine sociale. Bio-history is the term Michel Foucault initially uses - in the second lecture - to refer to the effect of the strong medical intervention at the biological level that started in the eighteenth century and has left a trace that is still visible in our society. It is on this occasion that Foucault introduces the concept, or rather the prefix "bio-" in his analysis, and it is here - as my reflections intend to demonstrate - that we may trace the original meaning of a term that today seems rather abused and find a valuable analytical framework for a cogent approach to the relationship between medicine and power dynamics.
\end{abstract}

Keywords: bio-history, social medicine, Michel Foucault, public health, institutions, COVID-19 pandemics.

\section{UWAGI O BIOHISTORII: MICHEL FOUCAULT I EKONOMIA POLITYCZNA ZDROWIA}

Streszczenie. W październiku 1974 roku Foucault wygłosił w Rio de Janeiro trzy wykłady na temat archeologii leczenia. W niniejszej pracy skomentowane zostaną dwa pierwsze, opublikowane kilka lat później we Francji pod oryginalnymi tytułami: Crise de la médicine ou crise de l'antimédicine? oraz La naissance de la médicine sociale. Biohistoria to termin, którego Michel Foucault używa początkowo - w drugim wykładzie - w odniesieniu do skutków silnej interwencji medycznej na poziomie biologicznym, która rozpoczęła się w XVIII wieku i pozostawiła ślad, który jest nadal widoczny w naszym społeczeństwie. To właśnie przy tej okazji Foucault wprowadza do swojej analizy pojęcie, a raczej przedrostek „bio-”, i to właśnie tutaj - jak zostanie pokazane w niniejszej pracy - możemy prześledzić pierwotne znaczenie terminu, który dziś wydaje się raczej nadużywany, jak też znaleźć wartościowe ramy analityczne dla przemyślanego podejścia do badań nad relacją pomiędzy medycyną a dynamiką władzy.

Słowa kluczowe: biohistoria, medycyna społeczna, Michel Foucault, zdrowie publiczne, instytucje, pandemia COVID-19.

\footnotetext{
*Institute for Cultural Inquiry, Berlin; xenia.chiaramonte@ici-berlin.org
} 


\section{INTRODUCTION}

The history of medicine is social and political. It is not only a kind of knowledge that passes through the individual exchange between doctor and patient but a knowledge that "forms part of a historical system." As such, "it is not a pure science, but is part of an economic system and of a system of power" (Foucault 2004, 19). Michel Foucault clarifies this point in October 1974, when he gave three lectures in Rio de Janeiro on the archeology of the cure. The first two - upon which I will comment on in this piece - were published a few years later in France with the original title: Crise de la médicine ou crise de l'antimédicine? and La naissance de la médicine sociale. It is on this occasion that Foucault introduces the concept, or rather the prefix "bio" in his analysis, and it is here - as my reflections intend to demonstrate - that we may trace the original meaning of a term that today seems rather abused and find a valuable analytical framework for a cogent approach to the relationship between medicine and power dynamics.

As is well known, the issue of biopolitics or biopower was, beginning with a series of research endeavors by the French philosopher, ${ }^{1}$ employed by many interpreters and in various disciplines, especially philosophy. The concept of biopolitics, defined as the taking charge of life by politics, ${ }^{2}$ or perhaps more drastically, as the right of death and power over life, ${ }^{3}$ continues to be called into question for different purposes by diverse parties, with greater or lesser reference to the overall reading of Foucault's oeuvre.

To avoid entering into a debate that would be difficult and too onerous to reconstruct here, I do not intend to address the age-old theme of biopolitics in its entirety, but to limit myself to sketching the phases of "bio-history." This purpose, however, is not based solely on a practical necessity. This piece argues that we shall look at the crossroads of medicine and society to recover the depth of what "bio" implies.

Bio-history is the term Michel Foucault initially uses - in the second lecture - to refer to what he defines as "the effect of medical intervention at the biological level, the imprint left of human history [...] by the strong medical intervention that began in the eighteenth century" (Foucault 2001a, 134).

As we can see, this is a definition that is both more specific and more complex than what Foucault will elsewhere provide under the prefix "bio." Bio-history is a specifically political history in which we are still fully involved. Hence, it is worth retracing the steps of this history to understand where we are today and

${ }^{1}$ In Society Must be Defended Foucault defines biopower as a concentration of interest that, starting from the second half of the eighteenth century, emerges as a technology of power that is exercised not on the man-body, "but in the direction of man-species" $(2003,242)$.

${ }^{2}$ See Foucault (2003), in particular, the lecture of 17 March 1976.

${ }^{3}$ See Foucault (1978), in particular, part V. 
how we can try to understand what is at stake, socially and politically in the current COVID-19 pandemics. I want the intent of these reflections to be clear: I do not desire to proclaim the last word on the current conditions of the pandemic or to be seduced by the temptation of prophecy (Weber 1949; Bourdieu, Chamboredon, Passeron 1991). I intend instead to show the ambiguities that have been circulating for some centuries around the matter of medicine, and its interconnection with legal and police matters, which can lead to various consequences - just as, in the past, they have led equally to the "glorious" years of the Welfare State and to authoritarian medicalization.

The proposal of this article is based on the fundamental premise that "[W]e are living a situation in which certain phenomena have led to a crisis. These phenomena have not fundamentally changed since the eighteenth century, a period that marked the appearance of a political economy of health with processes of generalized medicalization and mechanisms of bio-history" (Foucault 2004, 18).

\section{A SOMATOCRACY?}

As Foucault $(2004,7)$ writes, "[W]e live in a regime that sees the care of the body, corporal health, the relation between illness and health, etc. as appropriate areas of State intervention. It is precisely the birth of this somatocracy, in crisis since its origins, that I am proposing to analyze." We live in an era that considers the body, its health, and its disease to be crucial. It is not just the generic right to life that is at stake here, but the more specific and complex problematic that has taken the name of the right to health. Let us start by sketching the legal history of this protection.

With the well-known Beveridge plan, a system of reforms of the English social welfare (Hills et. al 1994) - from which Foucault's first intervention begins - we see the establishment of a model that will make history and will be the basis of various national constitutions, as well as of the Universal Declaration of Human Rights (United Nations, Paris 10 December 1948) and a ruling by the World Health Organization (1948). In particular, the report Social Insurance and Allied Services originally commissioned by Winston Churchill in 1939, was first publicized on 1 December 1942. It radically changed the social security system in the United Kingdom. The commission chaired by William Beveridge drew up a program based on the universality of public assistance. The establishment of the National Health Service (1948) aimed at guaranteeing the improvement of the physical and mental health of people through the prevention, diagnosis, and treatment of diseases, a program based on certain principles: the universality of access financed through general taxation.

Article 25 of the Universal Declaration of Human Rights, which was deeply influenced by the British NHS, states that: 
Everyone has the right to a standard of living adequate for the health and well-being of himself and of his family, including food, clothing, housing and medical care and necessary social services, and the right to security in the event of unemployment, sickness, disability, widowhood, old age or other lack of livelihood in circumstances beyond his control.

According to Foucault, this is a crucial turning point through which an old logic, according to which a healthy individual was at the service of the state, inverts its polarity: "the concept of the healthy individual in the service of the State was replaced by that of the State in the service of the healthy individual." In addition, "It is not only a question of a reversal of rights, but also of what might be called a morality of the body" (Foucault 2004, 6). Healthcare now enters the field of macroeconomics and becomes a decisive factor for statistical studies. In other words, the human body becomes the object of a story, and not the human body alone, but the human as a species among living beings, including its very relationship with other living beings. Admittedly, Foucault writes $(2004,11)$, "the history of man and life are profoundly intertwined. The history of man does not simply continue life, nor is it simply content to reproduce it, but to a certain extent renews it, and can exercise a certain number of fundamental effects on its processes."

Once healthcare has become central, and the state begins to serve a healthy population, authoritarian intervention - as we might notice today - also becomes possible through procedures such as mass screening or vaccination campaigns. In other words, taking care also means exercising control over individuals and, above all, over the "population", a concept that has a special place in the history of systems of thought, starting from the possibility of its management in hygienicsanitary terms. A population is the collective entity that allows the frequency with which disease spreads to become visible. The population facilitates knowledge of morbidity rates and becomes a statistical field divisible by age, the behavior of life, social position, and the coordinates of space and time. The population is the field in which dangers manifest and is the basis on which one understands how to act at the level of their government. In other words, it is through the population that criteria of normality (and therefore, obviously, normalization) can be elaborated. ${ }^{4}$

\footnotetext{
${ }^{4}$ Foucault dwells on the concept of population in several lessons in Security, Territory, Population and The Birth of Biopolitics. But above all, see The Politics of Health in Eighteenth Century, the version translated by Lynch, Richard A. $(2014,117)$, in which he states that "an element appeared at the center of this materiality, an element whose importance unceasingly asserted itself and grew in the seventeenth and eighteenth centuries: it was the population, understood in the already traditional sense of the number of inhabitants in proportion to the habitable area, but equally in the sense of an ensemble of individuals having between them relations of coexistence and constituting therefore a specific reality. The "population" has a growth rate; it has its mortality and morbidity; it has its conditions of existence, whether a question of the necessary elements for its survival or of those which permit its development and improvement. In appearance, it is a question of nothing but the sum of individual phenomena; nevertheless, one observes there constants and variables
} 
According to Foucault, in the eighteenth century, four major processes characterize consolidation of medicine: the emergence of "a medical authority, which is not restricted to the authority of knowledge" but that "can make decisions concerning a town, a district, an institution, or a regulation"; medicine becomes a "field of intervention" not only for diseases but with regard to the consequences of such things as "air, water, construction, terrains, sewerage"; the birth of the hospital: "Before the eighteenth century, the hospital was not an institution of medicalization, but of aid to the poor awaiting death; and finally, the "introduction of mechanisms of medical administration: recording of data, collection and comparison of statistics, etc." (Foucault 2004, 13).

This set of factors produces what Foucault calls the political economy of health. This means that, in contrast to the order of things before the eighteenth century, it is not enough to just provide for the health of individuals as a workforce, whether for reproductive or economic purposes. There is in fact a further step, which changes the role of medicine. Its connection with the economy certainly remains but becomes, in a certain sense, more complex. It is necessary that medicine is not only functional to the reproduction of the workforce but that it positively produces well-being. Well-being thenceforward acquires market value; it becomes a capitalizable asset:

Health becomes a consumer object, which can be produced by pharmaceutical laboratories, doctors, etc., and consumed by both potential and actual patients. As such, it has acquired economic and market value. Thus the human body has been brought twice over into the market: first by people selling their capacity to work, and second, through the intermediary of health. Consequently, the human body once again enters an economic market as soon as it is susceptible to diseases and health, to well being or to malaise, to joy or to pain, and to the extent that it is the object of sensations, desires, etc. (Foucault 2004, 16)

\section{THE QUARANTINE PLAN}

The centrality assumed by the body implies that the technologies of power do not act only on a "mental" level - a split between mind and body that now, as ever, holds little analytical value - nor do they function as a kind of propaganda:

Society's control over individuals was accomplished not only through consciousness or ideology but also in the body and with the body. For capitalist society, it was biopolitics, the biological, the somatic, the corporeal, that mattered more than anything else. The body is a political reality; medicine is a biopolitical strategy. (Foucault 2001a, 137)

The model that has been installed since the eighteenth century is more specifically the model of the plague, one no longer based on exclusion - like that of

which are proper to the population; and if one wishes to modify them, specific interventions are necessary.” See also Pandolfi (2006). 
leprosy (see also Foucault 1977) - but on permanent registration, detailed analysis, and constant inspection. In cases of plague or other types of epidemics, the ideal form of organization and control is the quarantine: one based on an "emergency plan" (Foucault 2001a, 144-145) and the loose concept of "measure" (see Napoli 2009).

In general, Foucault identifies three models in the history of social medicine: state medicine (Germany), urban medicine (France) and labor force medicine (England). Let us dwell on the French and the English models. Foucault defines the French model of social medicine in relation to urbanity. Urban medicine administered burial places and controlled and reduced the dangers that corpses posed, making air and hygienic conditions a fundamental stage of its "development." It is important to note, however, that these kinds of changes are not to be read exclusively with an eye toward the ethical. Foucault shows how cataloging, the control of circulation, and a new economy of the living and the non-living simultaneously took place alongside these processes. Consider this crucial example: in the eighteenth century we start dealing with death. It was not a matter of Christian respect for death and the corpse - this is precisely the ethical prejudice we need to avoid - but rather the emergence of a norm of public hygiene and a new political-health ideal that takes into account the living. Air quality and distance from the town were the basic factors calculated by an urban and political restructuring that led to the "first medical and urban policing sanctioned by the banishment of the cemeteries" (Foucault 2001a, 147).

Urban medicine focused more on things than on people; air, water, the general state of health. Healthiness is precisely not people's health; it rather refers to the concept of environment. The French constituent assemblies of 1870 and 1871 conceived public health on the basis of this latter concept. Poverty, writes Foucault, was not yet taken into consideration in terms of danger and fear. It is the English model that will produce this break in the second half of the nineteenth century, with the organization of a public health plan that, to guarantee the reproduction of the bourgeoisie, will result in mechanisms for the control and care of the poor: vaccination control, obligatory immunizations, the registering of epidemics (and possible indicators of contagious diseases to come), the location of unhealthy places, etc.

The controlling tendencies of this national Health Service "campaign" were so tangible that there was no shortage of forms of rebellion - which, paradoxically, those same public actions were aiming to avoid or radically eradicate. With the Poor Law Amendment Act, approved by the English Whig government in 1834, workhouses were established in which, as is well known, the poor were systematically exploited. These actions, then, were certainly not a matter of protecting human rights - a framework that did not yet exist - but a matter of defending a utilitarian cause: healthy environmental conditions would improve the health of the workforce and consequently increase the productivity of factories. The result: a happier, healthier, more productive, and ideally docile proletariat. According to Foucault, it is on the 
basis of the developments of the British model that our contemporary model of medicine - comprising medical assistance, control of the workforce, management of dangers, data collection, population screening, and mass vaccination campaigns - was formed (see Engels 1973; Mooney, Szreter 1998).

\section{THE POLITICS OF HEALTH}

A few years later, in 1976, Foucault returned to the issue, in a certain sense recapitulating what he had said more widely in the Rio de Janeiro conferences. I refer now to La politique de la santé au XVIII siècle, ${ }^{5}$ a short text that nevertheless clarifies important implications that his previous lectures had left unelaborated. Nosopolitics, literally a politics of the disease - writes Foucault $(2001 b, 92)$ - has not been a set of top-down strategies since the $18^{\text {th }}$ century, which would have imposed themselves vertically on the population.

The general plan was not so much to take care of needy people through assistance - although this was certainly also the case. Rather, something more radically innovative arises. The political and sanitary problem of the time revolved around the following issue: "how to raise the level of health of the social body as a whole", with the solution that was proposed based on standards of "physical wellbeing, health, and optimal longevity" (Foucault 2001b, 94). The practice required to obtain these three key principles of the new health policy was carried out by the "police." As we know, modern policing does not so much name a unitary institution as a set of police activities: economic regulation, measures of public order, rules of hygiene, etc. (Foucault 2001b, 94). ${ }^{6}$ In other words - at least in the French history - the police have embodied the administration of the social body: "The police, as an institutional ensemble and as a calculated modality of intervention, was responsible for the 'physical' element of the social body: the materiality, in some sense, of this civil society, about which in the same period, moreover, it was attempted to conceive the juridical status and forms" (Foucault 2014, 117).

How to defend the "newborn" society, this social body affected by diseases and susceptible to epidemic contagion? Medical care and police control were ultimately born together. Here, Foucault situates the birth of medicine at the intersection of an economy of assistance and a police of health. Once the diseases

\footnotetext{
${ }^{5}$ Here I refer to the English translation included in Power: The Essential Works of Foucault, 1954-1984, Vol. 3, translated into English by Colin Gordon. There are two similar versions under the same name of this text; the two texts appeared originally in volumes also bearing the same title, Les Machines à guérir [Curing Machines]. As in all other cases, I consulted the original text first and then consulted the English translation.

${ }^{6}$ For a study on the ambiguity of the "police" that historically develops this question and charts a Foucauldian approach, see Napoli (2003).
} 
of the poor have been included in the more general problem of the health of the population, we move from the ethical and charitable hypothesis of medical aid to a form of "medical police."

It is crucial, at this point, to understand the enabling conditions of this fundamental transformation. According to the French philosopher, the answer lies in the "accumulation of men", in the "demographic upswing in Western Europe" which made it necessary to develop "finer and more adequate power mechanisms" for the management of a growing population. At the same time, this population takes on the appearance of an "object of surveillance, analysis, intervention, modifications" (Foucault 2001b, 95). In this new technology of power, the family takes on a central role and becomes the "target for a great enterprise of medical acculturation" (ibid, 97) which is located in the interstices between private and public, keeping alive the private ethics of health, healthy reproduction, moral responsibility towards the child. Part of medicine is clearly practiced in the hospital institution, but it is also convenient for the market to maintain a domestic form of hospitalization.

In other words, public health is more a general technology that takes charge of forms of life and existence (including sexuality, reproductive capacity, and the risk of epidemic contagion) than a "simple" ethics of care. Quoting Rose, an important interpreter of Foucault, especially in the field of medicine, we might say that "the vital politics of our own century" is, in fact, "neither delimited by the poles of illness and health, nor focused on eliminating pathology to protect the destiny of the nation" $(2007,3)$. The current phase of public health and social medicine can be rather described as a politics of life itself, that is based on "our growing capacities to control, manage, engineer, reshape, and modulate the very vital capacities of human beings as living creatures." But what we mean by life? We shall comprehend what life really means and, therefore, how a bio-history can be advanced.

\section{LIVING IN AND WITH A NEW FORM OF LIFE?}

Let us now go back a few years, to the lectures in Rio de Janeiro in 1974. I would like to pause on two passages, in particular, to draw some important conclusions that this notion of bio-history can offer us in the present. The first excerpt is at the beginning of the second conference and contains an invitation: "it would be interesting to study the evolution of relations between humanity, the bacillary or viral field, and the interventions of hygiene, medicine, and the different therapeutic techniques." (Foucault 2001a, 135). The second passage is taken from the first conference and recalls an event - that, Foucault emphasizes, should not be forgotten - which took place in the zoological field, among nonhuman animals: "One must not forget that the first major epidemic studied in 
France in the eighteenth century and which led to a national data gathering was not really an epidemic but an epizootic" (Foucault 2004, 16).

Reading these two passages together, it seems clear that Foucault had grasped and intended to comprehend in the concept of bio-history a way of conducting archeology that should not remain within the confines of the events that bind human animals together. On the contrary, he intended to suggest the usefulness of an approach that would take into consideration all living beings. In the world of life, he seems to comprehend - certainly well in advance - also viral forms of life, "le champ viral." This aspect is extraordinarily original if we consider that, in the contemporary field of biology, there is an open debate about whether viruses are part of the tree of life or not. When the Coronavirus pandemic began, that debate was resumed and new contributions were published. This time an emergent consensus, which has the potential to enter the order of discourse, has begun to see the virus as a living form. Before, the virus was considered a parasite that only exploited the life of others. ${ }^{7}$ This is just an example of the "social" nature of the sciences, of their status as both historical and political, which are coterminous with power and change according to the contingency of events. From this methodological approach, we might analyze what happens in this conflictual field of knowledge and see what kind of hygienic norm it might lead to, how preventive and therapeutic techniques might change, and where the ensuing global data gathering might bring us.

To say that medicine is a social, historical, political matter, always linked to power, is to confirm what Rudolf Virchow himself - one of the "fathers" of social medicine (and thus perhaps of biopolitics) - said: "Medicine is a social science, and politics is nothing more than medicine in larger scale" (quoted by Waitzkin 2006, 7). ${ }^{8}$ As always, we need to understand what politics can be invented, what new institutions we can forge to give that "bio" one sense or another. "We move in a world of perpetual strategic relations. Every power relation is not bad in itself, but it is a fact that always involves danger" (Foucault 1990, 168).

The archeology of care is certainly useful for looking, with a gaze that is not too shrouded by ethics, at the events in which we inevitably participate. This awareness must also prevent idealizing a hypothetical past that never existed, an Eden that the world has never known (Haraway 1992), where people lived in harmony with so-called nature. A hypothetical "type of natural hygiene or paramedical bucolicism," writes Foucault, are "alternatives" that "do not make sense" (Foucault 2004, 18). As Foucault claims: "A series of phenomena, like the

${ }^{7}$ On this debate, see Moreira and López-García (2009), where the authors express ten reasons to exclude viruses from the tree of life; Claverie and Ogata (2009), on the contrary, propose ten reasons to include viruses in the evolutionary picture. This debate has recently restarted: see Harris and Hill (2021), who reconsider "a place for viruses on the tree of life."

${ }^{8}$ The reference is to Virchow (1958) and Virchow (1957). 
radical and bucolic rejection of medicine in favour of a non-technical reconciliation with nature, themes of millenarianism and the fear of an apocalyptic end of the species, represent the vague echo in public awareness of this technical uneasiness that biologists and doctors are beginning to feel with regards to the effects of their own practice and their own knowledge" (Foucault 2004, 12).

The vision of science as a kind of exact knowledge is still widespread and seems to be founded on the teleology of progress. What should be dismissed instead is precisely this (exclusively human) epic based on development (Stengers 2015). Indeed, with Latour, it is worth mentioning that "after a hundred years of socialism limited just to the redistribution of the benefits of the economy, it might now be more a matter of inventing a socialism that contests production itself. Injustice is not just about the redistribution of the fruits of progress, but about the very manner in which the planet is made fruitful" (Latour 2020). ${ }^{9}$

We are also in global mourning, but at the same time we are in a system of thought that struggles to conceive the inevitable risk contained in life: illness and death. ${ }^{10}$ "Life is what is capable of error"- this is what Foucault $(1991,22)$ writes in the introduction to the most important work by his master Georges Canguilhem, The Normal and The Pathological. Illness is not measured as a deviation from preestablished norms; it is a change in the quality of life. We need medicine because we are sick. Medicine cannot, therefore, arise from physiology, but necessarily from pathology. Pathology calls normality into question:

the consciousness of biological normality includes the relation to disease, the recourse to disease as the only touchstone which this consciousness recognizes and thus demands. [...] In order for the normal man to believe himself so, and call himself so, he needs not the foretaste of disease but its projected shadow. [...] health is an equilibrium which he redeems on inceptive ruptures. The menace of disease is one of the components of health. (Canguilhem 1991, 285-287)

\section{CONCLUSIONS}

A life under protection is also a life that surrenders itself, which is dependent on a certain idea of security, possibly expecting the realization of this security from the national state, and therefore inevitably under the conditions set by the state itself. In this regard, Foucault pointed out - in Un système fini face à une

\footnotetext{
${ }^{9} \mathrm{He}$ adds that "this does not mean de-growth, or living off love alone or fresh water. It means learning to select each segment of this so-called irreversible system, putting a question mark over each of its supposed indispensable connections, and then testing in more and more detail what is desirable and what has ceased to be so" (Latour 2020).

10 "Behind the doctor's back, death remained the great dark threat in which his knowledge and skill were abolished" $(1976,146)$ - wrote in The Birth of the Clinic: "it is at death that disease and life speak their truth: a specific, irreducible truth, protected from all assimilations to the inorganic by the circle of death that designates them for what they are" $(1976,145)$.
} 
demande infinie, 1983 - that we need to know "how people are going to accept being exposed to certain risks without being protected by the all-providing state" (Foucault 1990, 172). What Foucault did not have the opportunity to see completely - leaving this world prematurely, precisely because of a virus - is that healthcare has undergone an epochal turning point, in a neoliberal sense, in which centrality is given to the reason of market. ${ }^{11}$

However, the approach he proposed remains a fundamental one, inasmuch it provides us with a perspective for grasping the ambiguity of medicine: "what allows medicine to function with such force is that, unlike religion, it is inscribed in the scientific institution" (Foucault 2001c, 76) ${ }^{12}$ or, in other words: "one of the great functions of medicine [...] has been precisely to take the place of religion and reconvert sin into illness, to show that what was, what is sin, of course, may not be punished there, but will certainly be punished here" (Foucault 2001d, 1249). ${ }^{13}$

Foucault always intended to pause in the ambiguity, the complexity of the intertwining between knowledge and power, as in the following methodological warning: "We cannot simply designate the disciplinary effects of medicine. Medicine can work well as a mechanism of social control; it also has other functions, of technical and scientific types" (Foucault 2001c, 76). ${ }^{14}$ It is on the basis

${ }^{11}$ Various scholars have focused on how the eclipse of the concept of the right to health runs parallel to the WHO's loss of a leading role in international health policy to the benefit of the World Bank. In fact, in 1987, the World Bank published the first document on health: Financing Health Services in Developing Countries. An Agenda for Reforms. Its recipe is well known, advocating for: introduction of user fees (direct payment of services) in order to promote insurance programs, the privatization of health services, and the decentralization of health care. In this era of health (and its complex legal concept), new problems arise, mainly linked to the fact that the market has become the protagonist of our history of medicine. Vaccination campaigns follow the course of choices, clearly aligned with the profit motive, that pharmaceutical corporations establish. See the works of Howard Waitzkin: Medicine and Public Health at the End of Empire (2011), and Health Care Under the Knife: Moving Beyond Capitalism for Our Health (2018). In the journal Lancet, Julian Tudor Hart, a visionary general practitioner who set up preventive health care in a Welsh mining community back in 1971, wrote an article entitled Inverse Care Law: "The availability of good medical care tends to vary inversely with the need for it in the population served. This inverse care law operates more completely where medical care is most exposed to market forces, and less so where such exposure is reduced. The market distribution of medical care is a primitive and historically outdated social form, and any return to it would further exaggerate the maldistribution of medical resources" $(1971,405)$.

${ }^{12}$ My translation of "ce qui permet à la médecine de fonctionner avec une telle force, c'est que, contrairement à la religion, elle est inscrite dans l'institution scientifique" (2001c, 76).

${ }^{13}$ My translation of "l'une des grandes fonctions de la médecine [...] a été précisément de prendre le relais de la religion et de reconvertir le péché en maladie, de montrer que ce qui était, ce qui est péché bien sûr ne sera peut-être pas puni là-bas, mais sera certainement puni ici" (2001d, 1249). See the reflection of Agamben (2020).

${ }^{14}$ My translation of "On ne peut se contenter de désigner les effets disciplinaires de la médecine. La médecine peut bien fonctionner comme mécanisme de contrôle social, elle a aussi d'autres fonctionnements, techniques, scientifiques" (2001c, 76). 
of this complexity that the possibility of inventing new institutions, of building new practices, is always open, and ensures the duplicity of advances in techniques and their parallel potential for control. Foucault's reflections constitute a valuable compass for our practice:

We have to transform the field of social institutions into a vast experimental field, in such a way as to decide which taps need turning, which bolts need to be loosened here or there, to get the desired change; we certainly need to undertake a process of decentralization, for example, to bring the decision-making processes, thus avoiding the kind of grand totalizing integration that leaves people in complete ignorance of what is involved in this or that regulation. What we have to do then is to increase the experiments [...] bearing in mind that a whole institutional complex, at present very fragile, will probably have to undergo a restructuring from top to bottom. $(1990,165-166)$

\section{BIBLIOGRAPHY}

Agamben, Giorgio. 2020. "Medicine as religion." Itself/An und für sich, May 2, 2020. Translated by Adam Kotsko. https://itself.blog/2020/05/02/giorgio-agamben-medicine-as-religion/

Beveridge, William. 1942. Report: Social Insurance and Allied Services. London: HMSO.

Bourdieu, Pierre. Jean-Claude Chamboredon. Jean-Claude Passeron. 1991. The Craft of Sociology. Preliminary Remarks. Berlin-New York: Walter de Gruyter. https://doi. org/10.1515/9783110856460

Canguilhem, Georges. 1991. The Normal and the Pathological. New York: Zone Books.

Claverie, Jean-Michel. Hiroyuki Ogata. 2009. "Ten good reasons not to exclude viruses from the evolutionary picture." Nature Reviews Microbiology 7: 615. https://doi.org/10.1038/ nrmicro2108-c3

Engels, Friedrich. 1973. The Condition of the Working Class in England in 1844. Moscow: Progress Publishers.

Foucault, Michel. 1976. The Birth of the Clinic: An Archaeology of Medical Perception. Abingdon: Routledge.

Foucault, Michel. 1977. Discipline and Punish: The Birth of the Prison. New York: Random House. Foucault, Michel. 1978. The History of Sexuality. Vol. I. An Introduction. New York: Pantheon.

Foucault, Michel. 1990. "Social Security." In Politics, philosophy, culture. Interviews and other writings: 1977-1984. Abingdon: Routledge.

Foucault, Michel. 1991. "Introduction." In The Normal and the Pathological. Edited by Georges Canguilhem. New York: Zone Books.

Foucault, Michel. 2001a. "The Birth of Social Medicine." In Power: The Essential Works of Foucault. 1954-1984. Vol. 3. 134-156. Edited by James Faubion. Chicago: New Press.

Foucault, Michel. 2001b. "The Politics of Health in Eighteen Century." Translated by Colin Gordon. In Power: The Essential Works of Foucault. 1954-1984. Vol. 3. 90-105. Edited by James Faubion. Chicago: New Press.

Foucault, Michel. 2001c. "L'extension sociale de la norme.” In Dits et écrits. 1954-1988. Vol. II. 74-79. Paris: Gallimard.

Foucault, Michel. 2001d. "Les grandes fonctions de la medicine sociale dans notre société." In Dits et Écrits. 1954-1988. Vol. I. 110. [1248-1250]. Paris: Gallimard.

Foucault, Michel. 2003. "Society Must Be Defended.” Lectures at the Collège de France: 19751976. Paris: Picador. 
Foucault, Michel. 2004. "The Crisis of Medicine or the Crisis of Antimedicine?" Foucault Studies 1: 5-19. https://doi.org/10.22439/fs.v0i1.562

Foucault, Michel. 2014. "The Politics of Health in Eighteenth Century." Translated by Richard A. Lynch. Foucault Studies 18: 113-127. https://doi.org/10.22439/fs.v0i18.4654

Haraway, Donna. 1992. The Promises of Monsters: A Regenerative Politics for Inappropriateld Others. New York: Routledge.

Harris, Hugh. M.B. Colin Hill. 2021. "A Place for Viruses on the Tree of Life." Frontiers in Microbiology 11: 1-16. https://doi.org/10.3389/fmicb.2020.604048

Hart, Julian T. 1971. “Inverse Care Law.” Lancet 297: 405-412. https://doi.org/10.1016/S01406736(71)92410-X

Hills, John et al. Eds. 1994. Beveridge and Social Security: An International Retrospective. Oxford: Clarendon Press.

Latour, Bruno. 2020. "What protective measures can you think of so we don't go back to the precrisis production model?" Bruno Latour, March 30, 2020. http://www.bruno-latour.fr/sites/ default/files/downloads/P-202-AOC-ENGLISH_1.pdf

Moreira, David. Purificación López-García. 2009. "Ten reasons to exclude viruses from the tree of life." Nature reviews Microbiology 7: 306-311. https://doi.org/10.1038/nrmicro2108

Napoli, Paolo. 2003. Naissance de la police moderne. Pouvoir, normes, société. Paris: La Découverte. https://doi.org/10.3917/dec.napol.2003.01

Napoli, Paolo. 2009. "Misura di polizia: un approccio storico-concettuale in età moderna." Quaderni Storici 44: 523-547.

Pandolfi, Alessandro. 2006. "La 'natura' della popolazione.” In Governare la vita. Un seminario sui Corsi di Michel Foucault al Collège de France (1977-1979). Edited by Sandro Chignola. Ombre Corte: Verona.

Rose, Nikolas. 2007. The Politics of Life Itself. Biomedicine, Power, and Subjectivity in the TwentyFirst Century. Princeton: Princeton University Press. https://doi.org/10.1515/9781400827503

Stengers, Isabelle. 2015. In catastrophic times: resisting the coming barbarism. New Jersey: Open Humanity Press.

Szreter, Simon. Graham Mooney. 1998. "Urbanization, mortality, and the standard of living debate: new estimates of life at birth in nineteenth century British cities." Economic History Review 51: 84-112. https://doi.org/10.1111/1468-0289.00084

Virchow, Rudolf. 1957. Werk und Wirkung. Berlin: Rutten \& Loenig.

Virchow, Rudolf. 1958. Disease, Life, and Man. Stanford CT: Stanford University Press.

Waitzkin, Howard. 2006. "One and a half centuries of forgetting and rediscovering: Virchow's lasting contributions to Social Medicine." Social Medicine 1: 5-10.

Waitzkin, Howard. 2011. Medicine and Public Health at the End of Empire. Abingdon: Routledge.

Waitzkin, Howard, 2018. Health Care Under the Knife: Moving Beyond Capitalism for Our Health. New York: NYU Press.

Weber, Max. 1949. The Methodology of the Social Sciences. Illinois: The Free Press of Glencoe.

\section{Legal Acts}

The Poor Law Amendment Act: 14 August 1834.

The United Nations. 1948. Article 25. Universal Declaration of Human Rights. Paris. https://www. un.org/en/about-us/universal-declaration-of-human-rights

World Health Organization. 1948. Constitution. Geneva. https://www.who.int/governance/eb/who constitution_en.pdf 